6. Stukalo, N. and M. Lytvyn 2010. Derzhavne antykryzove rehulyuvannya bankivs'koho sektoru: dosvid YeS ta Ukrayiny [State anti-crisis regulation of the banking sector: experience of the EU and Ukraine]. Bulletin of the National Bank of Ukraine 7.

7. Chub, O. 2011. Bankivs'ki kryzy u hlobal'nomu seredovyshchi [Banking crises in the global environment]. Banking, 1.

УДК 658.14:330.146(045)

DOI: 10.31339/2617-0833-2019-2(27)-191-194

\author{
КАПІТАЛІЗАЦЇ̈ ПІДПРИСМСТВА - СУТНІСТЬ ТА ФУНКЦЇ̈ \\ Нестерова С.В., Обіцький А.А.
}

\title{
ESSENCE AND FUNCTIONS OF ENTERPRISE CAPITALIZATION
}

Nesterova Svitlana, Obitskyi Anatolij

Поняття капіталізації в економічній літературі розглядається з різних точок зору: як процес $і$ як результат. Крім того, відрізняють капіталізацію економіки, регіону і суб'єкта господарювання. Метою статті було охарактеризувати капіталізацію на рівні підприємства, як мікроекономічний індикатор успішності функиіонування.

На основі методу порівняльного аналізу запропоновано визначення: капіталізація підприємства - це інтегральна оцінка його вартості, щзо базується на обліку актуальних кількісних і якісних параметрів його господарського та фінансового стану. Дане визначення підкріплено функиіями, які виконує капіталізація підприємства в сучасній бізнес-середовищі: прогнозна, мобілізачійна, розподільна, стратегічна, стимулююча і інформаційна.

Ключові слова: капіталізачія, капіталізація підприємств, максимізація прибутку, розвиток.

The concept of capitalization in economic literature is considered from different points of view: As a process and as a result. In addition, the capitalization of the economy, the region and the subject of management is distinguished. The purpose of the article was to characterize capitalization at the enterprise level as a microeconomic indicator of success of operation. Based on the method of comparative analysis, a definition is proposed: The capitalization of the enterprise is an integral estimate of its value, based on the account of the actual quantitative and qualitative parameters of its economic and financial condition. This definition is supported by the functions that perform the capitalization of the enterprise in the modern business environment: Forecasting, mobilization, distribution, strategic, stimulating and information.

Key words: capitalization, enterprise capitalization, profit maximization, development.

Капіталізація суб'єкта економіки є одним із найважливіших фінансових індикаторів результативності функціонування. Рівень капіталізації сигналізує про розвиток економік, регіонів, окремих господарських одиниць.

Дослідження змісту, методів оцінки та значення капіталізації є предметом уваги низки науковців, як в Україні, так і закордоном. При цьому спостерігається різноманітність тлумачення терміну залежно від рівня застосування (макро-, мезо-, мікро-) та об'єкта, щодо якого розглядається дане поняття.

Так, група дослідників (Амосов О.Ю., Гавкалова Н.Л. [1], Горячук В.Ф. [3] та інші) проблеми підвищення капіталізації висвітлюють в площині макроекономічного фактору. На рівні регіону, впроваджуючи поняття «регіональна капіталізація», науковці - Пушкарчук I.M. [8], Музика I.C. [7] окреслюють чинники, що дозволяють оцінити потенціал територіального розвитку економіки. Мамонтова Н.А. [6] та Турило А.А. [9] висвітлюють капіталізацію 3 
позицій окремих бізнес-одиниць, таких як підприємство, компанія тощо. У роботі білоруського дослідника Корзьонка П.В. [5] зазначається, що термін «капіталізація» також може бути застосований і до певного активу.

Крім того, капіталізація зазвичай розглядається у діалектичному поєднанні як процес, як система, та як стан. Отже, аналіз наукових публікацій дозволяє стверджувати, що різноманітність підходів до визначення, подекуди протирічливих тлумачень вимагає доцільності вироблення спільного теоретико-методологічного пояснення сутності капіталізації.

Предметом нашого наукового інтересу в даній галузі $\epsilon$ дослідження сутності капіталізації підприємств, впливу на економічний розвиток суспільства, методів іiі виміру та способів підвищення.

Яким чином визначається капіталізація у роботі вітчизняних вчених? Так, Мамонтова Н.А, зазначає, що «капіталізація компанії - це інтегральна оцінка теперішньої вартості компанії, яка характеризується іiї основними показниками діяльності, приростом капіталу, ефективністю залучення інтелектуального та фінансового капіталу в умовах інноваційного розвитку» [6]. В даному визначені чітко прослідковується функціональновартісний аспект капіталізації як результат певних формалізованих розрахунків на основі кількісних і якісних критеріїв функціонування підприємства.

Давиденко Н. визначає капіталізацію як «комплекс дій, пов’язаних зі збільшенням обсягу капіталу корпорації та покращенням якості його формування й використанням для максимізації прибутку» [4,c.66]. Тут оціночний контекст капіталізації окреслений опосередковано, через мотивацію до збільшення прибутковості.

У роботі [5] капіталізацію визначено, як вартісну оцінку майна підприємства, 3 уточненням щодо орієнтації на поточні ринкові ціни. Очевидно, що дане трактування чітко орієнтоване на кількісні параметри, а відтак, стимулюють до пошуку загальноприйнятних та, за можливості, універсальних процедур такої оцінки.

У більшості досліджень капіталізація розглядається з позицій приросту власного капіталу підприємства. При цьому мова йде переважно про акціонерні товариства публічної форми власності, для яких цілком реально встановити ринкову вартість акцій.

Підсумовуючи зазначене, пропонуємо таке трактування терміну «капіталізація підприємства»: це інтегральна оцінка його вартості в ринкових цінах, заснована на врахуванні актуальних кількісних і якісних параметрів його господарсько-фінансового стану.

Таке визначення, на наше переконання, відповідає тим функціями, які покладаються на інше трактування капіталізації - як процес нарощення капіталу 3 метою максимізації прибутку, росту добробуту власників. Основними функціями капіталізації є:

Оцінююча функція - дозволяе скласти уявлення про наявні можливості підприємства, його ресурси, резерви та результативність фінансово-господарської діяльності. При реалізації даної функції слід брати до уваги таку характеристику, як складність та комплексність. Ринкова капіталізація - поняття багатоаспектне, і не завжди однозначне.

Прогностична - в певній мірі є логічним продовженням оціночної функції у аспекті виміру потенціалу ефективності діяльності, перспектив розвитку підприємства, його потенційної вартості у майбутньому. При цьому проявляється наступна риса: залежність від попиту. Збільшення чи зменшення показника ринкової капіталізації відбувається на засадах зміни попиту та пропозиції на цільовому ринку.

Мобілізаційна - створює умови для менш затратного способу залучення ресурсів за вартістю, часом, якісних характеристик тощо. На реалізацію цієї функції спрямована така характеристика як збільшення вартості капіталу.

Розподільча - забезпечує збалансованість економічної діяльності підприємства, створюючи умови для ефективного розподілу отриманих ресурсів для цілей процесу капіталізації.

Стратегічна - спрямована на використання досягнень високої капіталізації для 
здобуття, збереження та розширення набору конкурентних переваг підприємства, утримання своїх позицій на ринку. Реалізація даної функції спирається на таку характеристику як стратегічний характер. Функціонування підприємства - це, передусім, постійне прийняття управлінських рішень стратегічного характеру, як от вибір концепції розвитку, інвестиційної політики, способу нарощення ресурсної бази в умовах їх обмеженості і т.п.

Стимулююча - досягнутий високий рівень капіталізації мотивує до дій, що забезпечують його збереження та нарощення через ефективну маркетингову, науковотехнічну діяльність тощо. Дана функція активізується через усвідомлення однієї з важливих рис капіталізації, зокрема, динамічності. Динамічність проявляється в тому, що отримане значення капіталізації у певний момент часу залежить від багатьох факторів, які за своєю природою є мінливими та ймовірними. Зміна вихідних умов, при яких здійснювалась оцінка, призведе до зміни показника капіталізації підприємства. I не завжди в кращу сторону. Тому стимулююча функція спрацює «на випередження», забезпечуючи швидку реакцію на позитивні та негативні зміни зовнішньої кон'юнктури, такі як поява нових емітентів, інфляційні процеси в країні тощо.

Інформаційна - полягає у можливості оголосити про наявні та потенційні переваги підприємства на макро- та мікрорівні задля залучення уваги інвесторів. Так, однією 3 рис капіталізації, яку виділяє Шевченко, є орієнтація на маркетинг (інформаційність). Зокрема, на фондовому результат збільшення рівня ринкової капіталізації акціонерних товариств напряму залежить від своєчасного розміщення повної інформації про діяльність емітента.

Підсумовуючи означене, слід відміти що багатогранність поняття «капіталізація» дозволяє проводити його дослідження у різних площинах розвитку економіки, висвітлювати функції, характерні ознаки, методи нарощення, враховуючи множинність факторів впливу.

\section{Список використаних джерел}

1. Амосов О.Ю. Капіталізація як засіб модернізації суспільства / О.Ю. Амосов, Н.Л. Гавкалова // Науковий журнал «Демографія та соціальна економіка» - К.: НАН України, Ін-т демографії та соціальних досліджень імені М.В. Птухи НАН України, 2012. - № 1(17). - С.43-50.

2. Багацька К.В. Ринкова капіталізація компаній: світові та вітчизняні тенденції / К.В. Багацька, Б. І. Пюро // Облік і фінанси. - 2017. - №1(75). - С. 112-119.

3. Горячук В.Ф. Системний аналіз процесу капіталізації економіки країни та визначення його як системи [Електронний ресурс] / В.Ф. Горячук // Теорія та практика державного управління.- 2010.- №1 - Режим доступу: www.kbuara.kharkov.ua.

4. Давиденко Н. Концептуальні підходи до капіталізації підприємств / Н. Давиденко // Економічний часопис Східноєвропейського національного університету імені Лесі Українки. - 2016. - №1. - С.62-67.

5. Корзенок П.В. Методы повышения капитализации предприятий реального сектора экономики / П.В. Корзенок // Труды БГТУ. - 2017. - Серия 5, №1 . - С.278-281.

6. Мамонтова Н.А. Теоретико-методологічні засади капіталізації компаній // Фінансова система України. Наукові записки. Серія «Економіка». Випуск 17. - Остріг: Вид-во «Острозька академія», 2011 р. - С.232-239.

7. Музика I.C. Капіталізація як критерій досягнення ефективності управління кредитним потенціалом регіону [Електронний ресурс] / I. С. Музика. - Режим доступу: http://www.rusnauka.com/9_NND_2012/Economics/3_102285.doc.htm.

8. Пушкарчук I.M. Капіталізація як механізм підвищення конкурентоспроможності регіону / І.М. Пушкарчук // Економічний форум. - 2016. - №2. - С.137-145.

9. Турило А.А. Система критеріїв і показників оцінки капіталізації підприємства в процесі інноваційного розвитку / А.А. Турило, А.М. Турило //Актуальні проблеми економіки. - 2014. -№1(151). - С. 233-239. 
10. Шевченко Н.В. Ринкова капіталізація акціонерних товариств: сутність, функції та проблеми управління / Н.В. Шевченко // Економіка та держава. - 2011. - №9. - С. 2224.

\section{Reference}

1. Amosov, O.Yu. and Havkalova, N.L., 2012. Kapitalizatsiia yak zasib modernizatsii suspilstva. [Capitalization as a way to modernize society]. Demography and Social Economy, 1(17). pp. 43-50.

2. Bogatskaya, K.V. and Puro, B.I., 2017. Rynkova kapitalizatsiia kompanii: svitovi ta vitchyzniani tendentsii [Market Capitalization of Companies: Global and Domestic Trends]. Accounting and Finance, 1(75), pp. 112-119.

3. Horiachuk, V.F. 2010. Systemnyi analiz protsesu kapitalizatsii ekonomiky krainy ta vyznachennia yoho yak systemy [System analysis of the capitalization process of the country economy and its definition as a system]. The theory and practice of public administration. [online] Available at: www.kbuara.kharkov.ua.

4. Davydenko, N., 2016. Kontseptualni pidkhody do kapitalizatsii pidpryiemstv Conceptual approaches to enterprise capitalization]. Economic Journal of Lesya Ukrainka Eastern European National University, 1, pp. 62-67.

5. Korzenok, P.V., 2017. Metody povyshenyia kapytalyzatsyy predpryiatyi realnoho sektora ekonomyky Methods of increasing capitalization of enterprises of the real sector of economics]. Proceedings of BSU. Series 5, 1, pp. 278-281.

6. Mamontova, N.A., 2011 Teoretyko-metodolohichni zasady kapitalizatsii kompanii $\square$ Theoretical and methodological principles of company capitalization]. Financial system of Ukraine. Proceedings. Economy series, 17, pp. 232-239.

7. Musyka, I. S. 2012. Kapitalizatsiia yak kryterii dosiahnennia efektyvnosti upravlinnia kredytnym potentsialom rehionu Capitalization as a Criterion for Achieving the Efficiency of Credit Potential Management in the Region]. [online] Available at: http://www.rusnauka.com/9_NND_2012/Economics/3_102285.doc.htm.

8. Pushcharchuk, I.M., 2016. Kapitalizatsiia yak mekhanizm pidvyshchennia konkurentospromozhnosti rehionu Capitalization as a Mechanism for Increasing the Competitiveness of the Region]. Economic Forum, 2, pp. 137-145.

9. Turilo, A.A. and Turilo, A.M., 2014. Systema kryteriiv i pokaznykiv otsinky kapitalizatsii pidpryiemstva v protsesi innovatsiinoho rozvytku The system of criteria and indicators of the enterprise capitalization assessment in the process of innovative development]. Current problems of economy, 1(151), pp. 233-239.

10. Shevchenko, N.V., 2011. Rynkova kapitalizatsiia aktsionernykh tovarystv: sutnist, funktsii ta problemy upravlinnia Market capitalization of joint-stock companies: essence, functions and problems of management]. Economy and State, 9, pp. 22-24. 